ALICJA KALUS iD orcid.org/0000-0001-7397-3151

Instytut Psychologii, Uniwersytet Opolski, Opole Institute of Psychology, University of Opole, Opole e-mail: akalus@uni.opole.pl

JOANNA SZYMAŃSKA

e-mail: joannamszymanska@gmail.com

\title{
Odraczanie rodzicielstwa a ocena rodziny pochodzenia przez młodych dorosłych
}

\author{
Postponement of Parenthood and Evaluation of Family of Origin \\ by Young Adults
}

\begin{abstract}
Researchers of both contemporary family problems and statistical data point many important changes in family life. Among these, a significant place is occupied by the emergence of alternative forms of family life and transformation in the area of parenting (Dolińska, 2014; Golombok, 2015; Kemkes-Grottenthaler, 2003; Kwak, 2014; Mynarska 2009). Over the past years, the number of postponements or resignations from parental tasks has been increasing (CBOS, 2013b; GUS, 2016).

The purpose of this research was to explore the functioning of family of origin of spouses who did not undertake parental tasks. The study involved 210 people (105 women and 105 men) in early adulthood in legalized relationships, and the final analysis included results obtained from 170 people. The criterion group consisted of spouses who did not undertake parental tasks (76 persons) with minimum marital status of three years. The control group (94 persons) consisted of spouses of at least one child with a minimum marriage of three years.

The following research tools were used: Survey Questionnaire (own elaboration), Family Adaptability and Cohesion Scale Faces IV in Polish adaptation by Margasiński (2013). Studies have shown that spouses who do not take parental tasks assess their family of origin in a different way than spouses having children. These differences concerned the assessment of flexibility. However, the difference in the assessment of cohesion of families of origin occurred between women and men from the criterion group. The analyzes carried out showed that one and the other study group assesses their current family better than the family of origin.
\end{abstract}

Keywords: developmental tasks, parenthood, family system, alternative forms of family life

Słowa kluczowe: zadania rozwojowe, rodzicielstwo, system rodzinny, alternatywne formy życia rodzinnego 


\section{WPROWADZENIE}

Ostatnie dziesięciolecia przyniosły liczne zmiany rzeczywistości rodzinnej, których badania podjęli się zarówno socjologowie, demografowie, jak i psycholodzy. Demografowie zwracają uwagę na systematycznie malejące współczynniki dzietności (Abma, Martinez, 2006; Frejka, Sobotka, 2008; Kocot-Górecka, 2014). Na tle krajów Europy współczynnik dzietności w Polsce jest jednym z najniższych (zob. CBOS 2013b; GUS 2016). Konsekwencją tego stanu rzeczy jest zmiana struktury demograficznej społeczeństw i uniemożliwienie prostej zastępowalności pokoleń (Kotowska, 2009, 2014). Z jednej strony badania celów życiowych i planów młodych Polaków pokazują, że dziecko i rodzicielstwo ma dla nich duże znaczenie (zob. CBOS, 2013a,c, por. Dyczewski, 2007; Plopa, 2011; Szlendak, 2010), z drugiej zaś procent respondentów deklarujących chęć pozostania bezdzietnymi rośnie, a odsetek ten zwiększa się wraz z wiekiem (por. CBOS, 2010, 2012, 2013b).

Ważne miejsce wśród przemian w zakresie rodzicielstwa zajmuje m.in. niepodejmowanie zadań rodzicielskich przez osoby żyjące w małżeństwach lub związkach kohabitujących (Keizer i in. 2008; Mynarska, 2009, 2011a, 2011b; Park 2005; Rowland, 2007; Tanturri, Mencarini, 2008 oraz inni). Analiza zjawiska niepodejmowania zadań rodzicielskich pokazuje, że jest to zjawisko złożone, a motywy niepodejmowania zadań rodzicielskich w parze są zróżnicowane (Dolińska, 2014; Carmichael, Whittaker, 2007; Kwak, 2014). Dla niektórych osób jest to rezultat wcześnie podjętej decyzji o bezdzietności, którą zakładało jedno bądź obydwoje partnerów. W innych przypadkach może ona wynikać z odkładania poczęcia na później z uwagi na brak dogodnych warunków ekonomicznych bądź ambiwalentną postawę wobec rodzicielstwa (Cannold, 2004; Gillespie, 2003; McQuillan i in. 2012). W niniejszym projekcie niepodejmowanie zadań rodzicielskich będzie rozumiane jako odraczanie rodzicielstwa w określonej lub nieokreślonej perspektywie czasowej przez małżonków w okresie wczesnej dorosłości.
Na podstawie analizy literatury przedmiotu można uznać, że niewiele jest badań, w których poszukuje się rodzinnych uwarunkowań zjawiska niepodejmowania zadań rodzicielskich (DeLyser, 2012). Większość badaczy koncentruje swoją uwagę na socjologicznych i psychologicznych uwarunkowaniach indywidualnych decyzji prokreacyjnych, nie zaś na obrazie relacji między osobami w związkach, które nie podejmują zadań rodzicielskich, czy na obrazie rodzin pochodzenia (Gillespie, 2000, 2003; Hara, 2008; Letherby, 1994, 2002; Mynarska $\mathrm{i}$ in., 2014, Rich i in. 2011; Seiz, 2013).

Badacze rozwoju człowieka w kontekście rodziny podkreślają, że rodzicielstwo stanowi ważny obszar rozwoju jednostek, trudny do zastąpienia innymi doświadczeniami (Bakiera, 2003, 2004; Harwas-Napierała, 2003, 2009). Jego realizacja nabiera szczególnego znaczenia w okresie wczesnej dorosłości. To właśnie wczesna dorosłość stawia przed jednostką zadania rozwojowe, które wiążą się z odgrywaniem ról zawodowych i rodzinnych (Havighurst 1981; Plopa 2011; Gurba 2009). Obecnie wielu badaczy zwraca jednak uwage na zmiany w podejmowaniu zadań rozwojowych przez młodych dorosłych (Trempała, 2006; Wrzesień, 2003; Liberska, 2003). Ich przykładem jest coraz częstsze odraczanie rodzicielstwa przez młodych dorosłych (Farnicka, 2011; Carmichael, Whittaker, 2007; Kemkes-Grottenthaler, 2003).

Prowadzone dotychczas badania wskazują na znaczenie rodziny dla przystosowania jednostki i wykonywania przez nią zadań rozwojowych (Rostowska, 1995, 2000; Farnicka, 2011, 2013; Margasiński, 2015; Martowska, 2015; Radochoński, 2009). W tym kontekście ocena rodziny pochodzenia stanowi znaczący „fundament rozumienia rzeczywistości rodzinnej, wartości jej istnienia i zasad funkcjonowania" (Cierpka, 2013, s. 170). Szczególnego znaczenia nabiera to w chwili, gdy młodzi ludzie zaczynają tworzyć własną rodzinę. Badacze (Kaźmierczak, 2015; Cowan, Cowan, 1995; Matuszewska, 2003) zwracają uwagę na duże znaczenie rodziny pochodzenia w procesie adaptacji do ról macierzyńskich i ojcowskich. Nieliczne natomiast są bada- 
nia, które podejmują zagadnienie rodzinnych uwarunkowań odraczania rodzicielstwa, zarówno w trwały, jak i czasowy sposób. Z badań wynika, że bezdzietne kobiety postrzegają negatywnie macierzyństwo, najczęściej w kategoriach konieczności poświęcenia się, obarczenia obowiązkami, braku partnerstwa między kobietami a mężczyznami (Park, 2005; Bartosz, Bartak, 2010). W badaniach Helen Peterson (2015) respondentki odwoływały się do doświadczeń z rodzin pochodzenia i obrazu matek jako znudzonych, zmęczonych, ograniczonych przez odgrywane role. Doniesienia te są spójne z polskimi wynikami badań Bogny Bartosz i Katarzyny Bartak, które - analizując wywiady z kobietami dobrowolnie bezdzietnymi - wskazują na zasadnicze znaczenie relacji z matkami w kształtowaniu się negatywnych postaw wobec macierzyństwa (Bartosz, Bartak 2010). O podobnych doświadczeniach mówiły także kobiety badane przez Kristin Park (2005). Respondentki zwracały uwagę na obraz matki, który wynosiły z rodzin pochodzenia, jako kobiety niespełnionej. W innych badaniach wykazano, że obraz rodzicielstwa wyniesiony przez osoby dobrowolnie bezdzietne $\mathrm{z}$ rodzin pochodzenia jest wspólny dla obu płci (Carmichael, Whittaker, 2007). Ważne jest również zwrócenie uwagi na zadanie, które staje przed młodymi małżeństwami, jakim jest odseparowanie się od rodziny pochodzenia. Do głównych zadań, jakie stają przed małżonkami w okresie poprzedzającym pojawienie się dzieci należy przesunięcie lojalności wobec rodzin pochodzenia w stronę rodziny własnej (Kołbik, 1999). Mieczysław Plopa zwraca uwagę, że ,rodzina pochodzenia służy jako model do ustalania priorytetów i strategii rodziny" (2005, s. 20). W badaniach Marzanny Farnickiej $(2011,2013)$ zostało podkreślone znaczenie rodziny pochodzenia w podejmowaniu zadania, jakim jest rodzicielstwo. Mimo to autorka zwróciła uwagę na odmienność przebiegu transmisji międzypokoleniowej w przypadku podejmowania zadania rodzicielskiego w zależności od płci.

Podsumowując, zarówno dostępne dane demograficzne, jak i doniesienia z badań empirycznych w dziedzinie rozwoju człowie- ka w kontekście rodziny uzasadniają podjęty $\mathrm{w}$ artykule problem poszukiwania rodzinnych uwarunkowań odraczania zadań rodzicielskich w określonej lub nie perspektywie czasowej.

\section{PROBLEM BADAWCZY}

Uwzględniając wyniki dotychczasowych badań nad współczesnymi zmianami w obszarze niepodejmowania zadań rodzicielskich przez młodych dorosłych sformułowano cel badań, którym jest poszukiwanie rodzinnych uwarunkowań niepodejmowania zadań rodzicielskich przez młodych dorosłych. Oczekuje się, iż tak zaprojektowane badania uzupełnią dotychczasowe ustalenia w tym zakresie. Aby osiagnąc cel badań, sformułowano główne i szczegółowe pytania badawcze:

P 1. Czy ocena systemu rodziny pochodzenia przez małżonków niepodejmujących zadań rodzicielskich różni się - a jeśli tak to w zakresie jakich badanych zmiennych - od oceny systemu rodziny pochodzenia przez małżonków mających dzieci?

P 1.1. Czy istnieją istotne różnice w ocenie spójności rodziny pochodzenia między kobietami i mężczyznami z badanych grup?

P 1.2. Czy istnieją istotne różnice w ocenie elastyczności rodziny pochodzenia między kobietami i mężczyznami z badanych grup?

P 1.3. Czy istnieją istotne różnice w ocenie komunikacji w rodzinie pochodzenia między kobietami i mężczyznami z badanych grup?

P 2. Czy między małżonkami bezdzietnymi i dzietnymi istnieją różnice $\mathrm{w}$ zakresie oceny rodziny własnej i rodziny pochodzenia pod względem badanych zmiennych?

Sformułowane pytania badawcze stały się podstawą do wysunięcia hipotez badawczych do pytań szczegółowych. Nieliczne jak dotychczas badania empiryczne w zakresie niepodejmowania zadań rodzicielskich nie stanowią rzetelnej podstawy do stawiania hipotez kierunkowych, w związku z tym w pracy postawiono hipotezy dotyczące istnienia różnic między badanymi grupami.

H 1. Ocena systemu rodziny pochodzenia przez małżonków niepodejmujących zadań ro- 
dzicielskich różni się od oceny systemu rodziny pochodzenia małżonków mających dzieci.

H 1.1. Wystapią różnice w ocenie spójności rodziny pochodzenia pomiędzy kobietami i mężczyznami w grupie mającej dzieci i bezdzietnej.

H 1.2. Wystąpią różnice w ocenie elastyczności rodziny pochodzenia pomiędzy kobietami i mężczyznami w grupie będącej rodzicami i grupie niemającej dzieci.

H 1.3. Wystąpią różnice w ocenie komunikacji w rodzinie pochodzenia pomiędzy kobietami i mężczyznami w grupie rodziców i osób bezdzietnych.

Do pytania drugiego z uwagi na jego eksploracyjny charakter nie sformułowano hipotez.

\section{NARZĘDZIA BADAWCZE}

W badaniach użyto Kwestionariusza ankiety oraz Skali Oceny Rodziny (Faces IV w polskiej adaptacji Margasińskiego). Kwestionariusz ankiety został skonstruowany na potrzeby badania. Składa się z dwóch części. W pierwszej z nich zawarte są pytania dotyczące cech socjodemograficznych osób badanych, w drugiej części pytania dotyczą dziedziny rodzicielstwa i zbieraja dane, takie jak: posiadanie dzieci, możliwość posiadania dzieci, planowany czas poczęcia, przyczyny odkładania rodzicielstwa, stosowane środki antykoncepcyjne oraz jak - według osoby badanej - na powyższe pytania dotyczące chęci rodzicielstwa odpowiadał współmałżonek/ współmałżonka osoby badanej.

Autorem polskiej adaptacji kwestionariusza Faces IV - Flexibility and Cohesion Evaluation Scales Olsona jest Margasiński (2013); kwestionariusz opiera się na modelu kołowym Olsona, w którym rzeczywistość rodzinną opisują trzy wymiary: spójność (cohesion), elastyczność (flexibility), komunikacja (communication) (Olson, 2010; Olson, Gorall, 2006).

Spójność jest rozumiana jako „więź emocjonalna między członkami rodziny" (Margasiński, 2013, s. 12). Wśród wskaźników, poprzez które wyraża się spójność systemu, wymieniane są: bliskość między członkami rodziny, jakość psychologicznych granic pomiędzy członkami rodziny, koalicje, wielkość wspólnego czasu, za- interesowań, przyjaciół i form spędzania czasu wolnego, a także stopień, w jakim z pozostałymi osobami w rodzinie są omawiane ważne decyzje (zob. Margasiński, 2013). Wymiar ten jest wyrażany na trzech skalach: skali zrównoważonej spójności, skali niezwiązania i skali splątania. Narzędzie umożliwia też wyliczenie wskaźnika spójności systemu rodzinnego.

Elastyczność jest definiowana jako,,jakość i stopień zmian zachodzących w systemach, związanych z przywództwem, odgrywanymi rolami i zasadami wzajemnych relacji oraz wynikających z procesów negocjacyjnych pomiędzy członkami rodziny" (Margasiński, 2013, s. 12). Wśród wskaźników opisujących omawiany wymiar są wymieniane: zakres przyjmowania przywództwa, style prowadzenia negocjacji, role przyjmowane przez członków rodziny, reguły opisujące związki między członkami rodziny (Margasiński, 2013, s.13). Podobnie jak w przypadku spójności wymiar elastyczności jest wyrażany na jednej skali zrównoważenia: zrównoważona elastyczność, oraz na dwóch skalach niezrównoważenia: sztywność i chaotyczność. Możliwe jest także obliczenie wskaźnika elastyczności.

Trzecim wymienianym wymiarem jest komunikacja, czyli „umiejętności pozytywnego porozumiewania się (...) w danym systemie" (Margasiński 2015, s. 24). Uważa się ją za wymiar pomocniczy względem dwóch wcześniejszych. Jej wysoki poziom uznaje się za warunek zmian poziomów spójności i elastyczności. Skale użyte w omawianym kwestionariuszu to: zrównoważona spójność, zrównoważona elastyczność, niezwiązanie, splątanie, sztywność, chaotyczność i komunikacja. Współczynniki rzetelności skal kwestionariusza ( $\alpha$ Cronbacha) mieszczą się w granicach od 0,70 do 0,93.

W badaniu użyto kwestionariusza w dwóch wersjach, prosząc respondentów, aby najpierw wypełniali kwestionariusz, odnosząc się do aktualnych systemów rodzinnych, a następnie do rodziny pochodzenia. Instrukcja brzmiała: „Określ, w jakim stopniu zgadzasz się z poniższymi stwierdzeniami, odnosząc je do swojej aktualnej rodziny”, a następnie: „Określ, w jakim stopniu zgadzasz się z poniższymi stwierdzeniami, odnosząc je do rodziny, z której pochodzisz". 


\section{GRUPA BADANA}

Badaniami objęto 210 osób w wieku 25-40 lat, będących w związkach małżeńskich z przynajmniej trzyletnim stażem. Staż małżonków wynosił co najmniej trzy lata, zgodnie z teorią Duvall (1977), która dwa pierwsze lata małżeństwa określa mianem matżeństwa bez dziecka, kolejny rok natomiast dodano ze względu na czas, który uznaje się za konieczny dla diagnostyki niepłodności (Bielawska-Batorowicz, 2014). Po odrzuceniu kwestionariuszy, w których wystapiły braki lub niejasności, oraz po odrzuceniu małżonków niespełniających założonych kryteriów, do ostatecznych analiz zakwalifikowano wyniki uzyskane przez 170 osób. Grupę kryterialną stanowili małżonkowie niepodejmujący zadań rodzicielskich (76 osób). Kryterium doboru do grupy stanowiły: bezdzietność i odkładanie poczęcia na co najmniej rok, podejmowanie kroków w celu zabezpieczenia się przed niechcianą ciążą, brak przeszkód natury medycznej do poczęcia. W momencie przeprowadzania badań małżonkowie ci nie mieli dzieci i deklarowali, że obecnie nie chcą ich mieć. Grupę kontrolną stanowiły 94 osoby - byli to małżonkowie mający przynajmniej jedno dziecko.

\section{WYNIKI}

Analizy rozpoczęto od obliczenia różnic między kobietami i mężczyznami testem t-Studenta, który jest wykorzystywany do porównania różnic w wartościach średnich między dwiema grupami, aby zweryfikować, czy kobiety i mężczyźni dzietni i bezdzietni różnią się między sobą w badanych wymiarach oraz czy mężczyźni dzietni różnią się od mężczyzn bezdzietnych, a także czy kobiety dzietne różnią się od kobiet bezdzietnych. Mimo braku rozkładu normalnego zdecydowano się na użycie testów parametrycznych. Testy te wykonano po analizie wykresów normalności, w których linią prostą estymowano rozkład Gaussa, a wyniki wykazały niewielkie odchylenia od normalności.

Tabela 1 przedstawia średnie odpowiedzi respondentów w każdej z grup z podziałem na płeć.

Przeprowadzone analizy wskazują na istnienie jednej różnicy (istotnej na poziomie tendencji statystycznej $(t(74)=-1,773 ; p=, 080)$ między mężczyznami a kobietami w grupie niepodejmującej zadań rodzicielskich na skali splątanie. Mężczyźni bezdzietni mają wyższe (średnia $=14,24$ ) od kobiet bezdzietnych (średnia $=12,55)$ wyniki $\mathrm{w}$ skali splątanie $\mathrm{w}$ odniesieniu do rodziny pochodzenia.

Tabela 1. Statystyki opisowe dla wymiaru spójności rodziny pochodzenia w podziale na płeć i podejmowanie zadań rodzicielskich

\begin{tabular}{|c|c|c|c|c|c|c|c|c|}
\hline \multirow{3}{*}{$\begin{array}{l}\text { Wymiar spójności } \\
\text { rodziny pochodzenia }\end{array}$} & \multicolumn{4}{|c|}{ Małżeństwo bezdzietne $(N=76)$} & \multicolumn{4}{|c|}{ Małżeństwa dzietne $(N=94)$} \\
\hline & \multicolumn{2}{|c|}{$\begin{array}{l}\text { Kobieta } \\
(N=\mathbf{3 8})\end{array}$} & \multicolumn{2}{|c|}{$\begin{array}{l}\text { Mężczyzna } \\
(N=\mathbf{3 8})\end{array}$} & \multicolumn{2}{|c|}{$\begin{array}{l}\text { Kobieta } \\
(N=47)\end{array}$} & \multicolumn{2}{|c|}{$\begin{array}{l}\text { Mężczyzna } \\
(N=47)\end{array}$} \\
\hline & $M$ & $S D$ & $M$ & $S D$ & $M$ & $S D$ & $M$ & $S D$ \\
\hline $\begin{array}{l}\text { Zrównoważona spójność rodzina } \\
\text { pochodzenia }\end{array}$ & 26,97 & 5,54 & 26,32 & 5,26 & 26,62 & 5,88 & 26,85 & 5,80 \\
\hline $\begin{array}{l}\text { Niezwiazzanie rodzina } \\
\text { pochodzenia }\end{array}$ & 15,97 & 6,61 & 16,24 & 5,62 & 14,77 & 5,94 & 14,91 & 5,56 \\
\hline $\begin{array}{l}\text { Splątanie rodzina pochodzenia } \\
\text { rodzina pochodzenia }\end{array}$ & 12,55 & 4,00 & 14,24 & 4,27 & 13,43 & 4,92 & 14,11 & 4,28 \\
\hline $\begin{array}{l}\text { Wskaźnik spójności rodzina } \\
\text { pochodzenia }\end{array}$ & 2,12 & 0,88 & 1,92 & 0,86 & 2,20 & 1,11 & 2,10 & 1,02 \\
\hline
\end{tabular}


Tabela 2. Statystyki testu t-Studenta różnic między osobami w podziale na płeć i podejmowanie zadań rodzicielskich dla wymiaru spójności rodzin pochodzenia

\begin{tabular}{|c|c|c|c|c|c|c|c|c|c|c|c|c|}
\hline \multirow{3}{*}{$\begin{array}{l}\text { Wymiar spójności } \\
\text { rodziny pochodzenia }\end{array}$} & \multicolumn{12}{|c|}{ Statystyki testu t-Studenta różnic między różnymi parami osób } \\
\hline & \multicolumn{3}{|c|}{ Mdz-Kdz } & \multicolumn{3}{|c|}{ Mbd-Kbd } & \multicolumn{3}{|c|}{ Mbd-Mdz } & \multicolumn{3}{|c|}{ Kdz-Kbd } \\
\hline & $T$ & $D f$ & $p$ & $T$ & $d f$ & $p$ & $T$ & $d f$ & $P$ & $t$ & $D f$ & $P$ \\
\hline $\begin{array}{l}\text { Zrównoważona spójność } \\
\text { rodzina pochodzenia }\end{array}$ & $-0,194$ & 92 & 0,846 & 0,531 & 74 & 0,597 & $-0,441$ & 83 & 0,661 & 0,285 & 83 & 0,776 \\
\hline $\begin{array}{l}\text { Niezwiązanie rodzina } \\
\text { pochodzenia }\end{array}$ & $-0,125$ & 92 & 0,900 & $-0,187$ & 74 & 0,852 & 1,084 & 83 & 0,281 & 0,886 & 83 & 0,378 \\
\hline $\begin{array}{l}\text { Splątanie rodzina } \\
\text { pochodzenia }\end{array}$ & $-0,716$ & 92 & 0,476 & $-1,773$ & 74 & 0,080 & 0,140 & 83 & 0,889 & $-0,883$ & 83 & 0,380 \\
\hline $\begin{array}{l}\text { Wskaźnik spójności } \\
\text { rodzina pochodzenia }\end{array}$ & 0,440 & 92 & 0,661 & 0,980 & 74 & 0,330 & $-0,865$ & 83 & 0,390 & $-0,364$ & 83 & 0,717 \\
\hline
\end{tabular}

Drugi wymiar modelu Olsona stanowi elastyczność; jest ona mierzona na trzech skalach: zrównoważonej elastyczności, chaotyczności i sztywności. Wyliczono także wskaźnik elastyczności. Średnie odpowiedzi kobiet i mężczyzn z każdej z badanych grup prezentuje tabela 3 .

Przeprowadzone analizy wskazują na istnienie wyraźnych różnic pomiędzy mężczyznami z grupy niepodejmującej zadań rodzicielskich i z grupy mającej dzieci w skali zrównoważonej elastyczności i we wskaźniku elastyczności. Mężczyźni z małżeństw bezdzietnych na skali zrównoważonej elastyczności rodziny pochodzenia mają istotnie $((t(83)=-2,340 ; p=.022))$ niższe średnie wyniki (średnia $=22,26)$ od mężczyzn z małżeństw mających dzieci (średnia $=$ 24,77). Różnice w ocenie elastyczności rodzin pochodzenia pomiędzy mężczyznami z obu badanych grup potwierdza także różnica we

Tabela 3. Statystyki opisowe dla wymiaru elastyczności rodzin pochodzenia w podziale na płeć i podejmowanie zadań rodzicielskich

\begin{tabular}{|c|c|c|c|c|c|c|c|c|}
\hline \multirow{3}{*}{ Wymiar elastyczności } & \multicolumn{4}{|c|}{$\begin{array}{l}\text { Malżeństwo bezdzietne } \\
\qquad(N=76)\end{array}$} & \multicolumn{4}{|c|}{ Małżeństwa dzietne $(N=94)$} \\
\hline & \multicolumn{2}{|c|}{$\begin{array}{l}\text { kobieta } \\
(N=\mathbf{3 8})\end{array}$} & \multicolumn{2}{|c|}{$\begin{array}{l}\text { mężczyzna } \\
(N=38)\end{array}$} & \multicolumn{2}{|c|}{$\begin{array}{l}\text { kobieta } \\
(N=47)\end{array}$} & \multicolumn{2}{|c|}{$\begin{array}{l}\text { mężczyzna } \\
(N=47)\end{array}$} \\
\hline & $M$ & $S D$ & $M$ & $S D$ & $M$ & $S D$ & $M$ & $S D$ \\
\hline $\begin{array}{l}\text { Zrównoważona elastyczność ro- } \\
\text { dzina pochodzenia }\end{array}$ & 22,74 & 4,18 & 22,26 & 4,72 & 23,17 & 6,02 & 24,77 & 5,05 \\
\hline Sztywność rodzina pochodzenia & 18,47 & 3,64 & 18,68 & 4,65 & 19,15 & 5,05 & 19,45 & 4,59 \\
\hline $\begin{array}{l}\text { Chaotyczność rodzina pocho- } \\
\text { dzenia }\end{array}$ & 17,84 & 5,47 & 17,76 & 4,11 & 16,49 & 5,51 & 16,36 & 5,50 \\
\hline $\begin{array}{l}\text { Wskaźnik elastyczności rodzina } \\
\text { pochodzenia }\end{array}$ & 1,30 & 0,35 & 1,27 & 0,39 & 1,35 & 0,45 & 1,43 & 0,42 \\
\hline
\end{tabular}


wskaźniku elastyczności. Wskaźnik elastyczności rodzin pochodzenia mężczyzn niepodejmujących zadań rodzicielskich jest niższy $($ średnia $=1,27)$ niż mężczyzn $\mathrm{z}$ małżeństw mających dzieci (średnia $=1,43$ ) (istotność na poziomie tendencji statystycznej $(t(83)=$ $-1,868 ; p=.065)$.

Komunikacja, będąca trzecim wymiarem modelu Olsona, nie różnicuje istotnie badanych grup. Tabela 5 prezentuje wyniki respondentów w każdej z badanych grup w podziale na płeć.

Przeprowadzone analizy nie potwierdzają występowania różnic między kobietami i mężczyznami z badanych grup w ocenie komunikacji w rodzinie pochodzenia. Statystyki testu t-Studenta prezentuje tabela 6 .
Aby odpowiedzieć na zadane pytanie P2: czy między małżonkami bezdzietnymi i dzietnymi istnieją różnice $\mathrm{w}$ zakresie oceny rodziny własnej $\mathrm{w}$ porównaniu $\mathrm{z}$ rodziną pochodzenia pod względem badanych zmiennych, obliczono test t-Studenta dla prób zależnych. W pierwszej kolejności analizowano, czy istnieją różnice statystycznie istotne w obrębie tych samych zmiennych w dwóch grupach. Następnie za pomocą testu t-Studenta dla prób niezależnych sprawdzono, czy małżonkowie dzietni i bezdzietni różnią się między sobą w zakresie oceny porównawczej systemu rodziny pochodzenia do aktualnego systemu rodzinnego.

W skalach zrównoważona spójność, zrównoważona elastyczność, komunikacja, wskaź-

Tabela 4. Statystyki testu t-Studenta różnic między osobami w podziale na płeć i podejmowanie zadań rodzicielskich dla wymiaru elastyczności rodziny pochodzenia

\begin{tabular}{|l|c|c|c|c|c|c|c|c|c|c|c|c|}
\hline \multirow{2}{*}{$\begin{array}{l}\text { Wymiar elastyczności } \\
\text { rodziny pochodzenia }\end{array}$} & \multicolumn{6}{|c|}{ Statystyki testu t-Studenta różnic między różnymi parami osób } \\
\cline { 2 - 13 } & \multicolumn{2}{|c|}{ Mdz-Kdz } & \multicolumn{2}{c|}{ Mbd-Kbd } & \multicolumn{2}{c|}{ Mbd-Mdz } & \multicolumn{3}{c|}{ Kdz-Kbd } \\
\cline { 2 - 13 } & $\boldsymbol{T}$ & $\boldsymbol{d} \boldsymbol{f}$ & $\boldsymbol{P}$ & $\boldsymbol{T}$ & $\boldsymbol{d}$ & $\boldsymbol{p}$ & $\boldsymbol{T}$ & $\boldsymbol{d} \boldsymbol{f}$ & $\boldsymbol{P}$ & $\boldsymbol{t}$ & $\boldsymbol{d} \boldsymbol{f}$ & $\boldsymbol{P}$ \\
\hline $\begin{array}{l}\text { Zrównoważona elastycznośćc } \\
\text { rodzina pochodzenia }\end{array}$ & $-1,392$ & 92 & 0,167 & 0,463 & 74 & 0,645 & $\mathbf{- 2 , 3 4 0}$ & $\mathbf{8 3}$ & $\mathbf{0 , 0 2 2}$ & $-0,376$ & 83 & 0,708 \\
\hline $\begin{array}{l}\text { Sztywność rodzina } \\
\text { pochodzenia }\end{array}$ & $-0,299$ & 92 & 0,765 & $-0,220$ & 74 & 0,827 & $-0,757$ & 83 & 0,451 & $-0,691$ & 83 & 0,491 \\
\hline $\begin{array}{l}\text { Chaotyczność rodzina } \\
\text { pochodzenia }\end{array}$ & 0,112 & 92 & 0,911 & 0,071 & 74 & 0,944 & 1,303 & 83 & 0,196 & 1,129 & 83 & 0,262 \\
\hline $\begin{array}{l}\text { Wskaźnik elastyczności } \\
\text { rodzina pochodzenia }\end{array}$ & $-0,936$ & 92 & 0,352 & 0,351 & 74 & 0,727 & $-\mathbf{1 , 8 6 8}$ & $\mathbf{8 3}$ & $\mathbf{0 , 0 6 5}$ & $-0,572$ & 83 & 0,569 \\
\hline
\end{tabular}

Tabela 5. Statystyki opisowe wymiaru komunikacji w rodzinie pochodzenia w podziale na płeć i podejmowanie zadań rodzicielskich

\begin{tabular}{|l|c|c|c|c|c|c|c|c|}
\hline \multirow{2}{*}{ Wymiar komunikacji } & \multicolumn{2}{|c|}{ Malżeństwo bezdzietne $(\boldsymbol{N}=\mathbf{7 6})$} & \multicolumn{2}{c|}{ Malżeństwa dzietne (N=94) } \\
\cline { 2 - 9 } & \multicolumn{2}{|c|}{$\begin{array}{c}\text { Kobieta } \\
(\boldsymbol{N}=\mathbf{3 8})\end{array}$} & $\begin{array}{c}\text { Mężczyzna } \\
(\boldsymbol{N}=\mathbf{3 8})\end{array}$ & \multicolumn{2}{|c|}{$\begin{array}{c}\text { Kobieta } \\
(\boldsymbol{N}=\mathbf{4 7})\end{array}$} & \multicolumn{2}{c|}{$\begin{array}{c}\text { Mężczyzna } \\
(\boldsymbol{N}=\mathbf{4 7})\end{array}$} \\
\cline { 2 - 9 } & $\boldsymbol{M}$ & $\boldsymbol{S D}$ & $\boldsymbol{M}$ & $\boldsymbol{S D}$ & $\boldsymbol{M}$ & $\boldsymbol{S D}$ & $\boldsymbol{M}$ & $\boldsymbol{S D}$ \\
\hline $\begin{array}{l}\text { Komunikacja rodzina } \\
\text { pochodzenia }\end{array}$ & 36,87 & 9,31 & 36,84 & 9,37 & 35,85 & 9,38 & 37,91 & 8,26 \\
\hline
\end{tabular}


Tabela 6. Statystyki testu t-Studenta różnic między kobietami i mężczyznami z grupy małżeństw dzietnych i bezdzietnych w zakresie komunikacji rodzinnej rodzin pochodzenia

\begin{tabular}{|l|c|c|c|c|c|c|c|c|c|c|c|c|c|}
\hline \multirow{2}{*}{$\begin{array}{l}\text { Wymiar komunikacji } \\
\text { rodziny pochodzenia }\end{array}$} & \multicolumn{6}{|c|}{ Statystyki testu t-Studenta różnic między różnymi parami osób } \\
\cline { 2 - 13 } & \multicolumn{2}{|c|}{ Mdz-Kdz } & \multicolumn{2}{|c|}{ Mbd-Kbd } & \multicolumn{3}{c|}{ Mbd-Mdz } & \multicolumn{3}{|c|}{ Kdz-Kbd } \\
\cline { 2 - 12 } & $\boldsymbol{T}$ & $\boldsymbol{d}$ & $\boldsymbol{p}$ & $\boldsymbol{T}$ & $\boldsymbol{d}$ & $\boldsymbol{P}$ & $\boldsymbol{T}$ & $\boldsymbol{d} \boldsymbol{f}$ & $\boldsymbol{P}$ & $\boldsymbol{t}$ & $\boldsymbol{d} \boldsymbol{f}$ & $\boldsymbol{p}$ \\
\hline $\begin{array}{l}\text { Komunikacja rodzina } \\
\text { pochodzenia }\end{array}$ & $-1,132$ & 92 & 0,260 & 0,012 & 74 & 0,990 & $-0,561$ & 83 & 0,577 & 0,499 & 83 & 0,619 \\
\hline
\end{tabular}

Tabela 7. Statystyki opisowe i testu t-Studenta dla prób zależnych i niezależnych w zakresie różnic w ocenie porównawczej systemów rodziny pochodzenia (r.p) do rodziny własnej (r.w.)

\begin{tabular}{|c|c|c|c|c|c|c|c|c|c|c|}
\hline \multirow[b]{2}{*}{ Nazwa skali } & \multicolumn{2}{|c|}{$\begin{array}{c}\text { Malżonkowie } \\
\text { dzietni }\end{array}$} & \multicolumn{2}{|c|}{$\begin{array}{c}\text { Różnica } \\
\text { między oce- } \\
\text { ną rodziny } \\
\text { pochodzenia } \\
\text { a własną }\end{array}$} & \multicolumn{2}{|c|}{$\begin{array}{c}\text { Malżonkowie } \\
\text { bezdzietni }\end{array}$} & \multicolumn{2}{|c|}{$\begin{array}{c}\text { Różnica } \\
\text { między oce- } \\
\text { ną rodziny } \\
\text { pochodzenia } \\
\text { a własną }\end{array}$} & \multicolumn{2}{|c|}{$\begin{array}{l}\text { Porównanie róż- } \\
\text { nic w ocenie ro- } \\
\text { dziny pochodze- } \\
\text { nia i własnej } \\
\text { między dwoma } \\
\text { badanymi } \\
\text { grupami }\end{array}$} \\
\hline & M r.p. & M r.w. & $\mathrm{t}$ & $\mathrm{P}$ & M r.p. & M r.w. & $\mathrm{t}$ & $\mathrm{P}$ & $\mathrm{t}$ & $\mathrm{P}$ \\
\hline $\begin{array}{l}\text { Zrównoważona } \\
\text { spójność }\end{array}$ & 26,73 & 30,34 & 5,774 &, 000 & 26,64 & 29,93 & 4,669 & ,000 &,- 348 &, 728 \\
\hline Niezwiązanie & 14,84 & 10,95 & $-6,519$ &, 000 & 16,11 & 12,3 & $-5,214$ &, 000 & ,097 & ,922 \\
\hline Splątanie & 13,77 & 13,44 &,- 627 &, 532 & 13,39 & 13,8 & 857 & ,394 & 1,018 & ,310 \\
\hline $\begin{array}{l}\text { Wskaźnik } \\
\text { spójności }\end{array}$ & 2,15 & 2,72 & 5,100 &, 000 & 2,02 & 2,48 & 4,418 & ,000 &,- 671 &, 503 \\
\hline $\begin{array}{l}\text { Zrównoważona } \\
\text { elastyczność }\end{array}$ & 23,97 & 27,1 & 4,425 &, 000 & 22,5 & 25,26 & 4,619 & ,000 &,- 383 & ,702 \\
\hline Sztywność & 19,3 & 19,76 & ,916 &, 362 & 18,58 & 17,89 & $-1,350$ & ,181 & $-1,589$ &, 114 \\
\hline Chaotyczność & 16,43 & 15,83 &,- 983 & ,328 & 17,8 & 16,92 & $-1,421$ & , 159 &,- 327 &, 744 \\
\hline $\begin{array}{l}\text { Wskaźnik } \\
\text { elastyczności }\end{array}$ & 1,39 & 1,58 & 3,547 & ,001 & 1,28 & 1,52 & 3,996 & ,000 &, 573 &, 567 \\
\hline Komunikacja & 36,88 & 42,06 & 5,027 &, 000 & 36,86 & 42,64 & 5,428 & ,000 & ,407 & ,684 \\
\hline
\end{tabular}

nik spójności oraz we wskaźniku elastyczności wszystkie badane osoby oceniają system rodziny pochodzenia niżej niż system aktualnej rodziny własnej. Tylko na skali niezwiązanie istotnie wyżej oceniana jest rodzina pochodzenia. Porównanie różnic $\mathrm{w}$ ocenie rodziny pochodzenia i własnej między dwoma badanymi grupami nie wykazało wartości istotnych statystycznie. Nie istnieją więc istotne różnice pomiędzy badanymi grupami w porównaniu systemów rodzin pochodzenia $\mathrm{z}$ rodzinami własnymi.

\section{DYSKUSJA}

Jak wspomniano w części teoretycznej artykułu, dotychczasowe badania wykazały znaczenie systemu rodzinnego dla rozwoju jednostek (Margasiński, 2015; Radochoński, 2009; Rostowska, 1995). Idąc tym tokiem myślenia, postanowiono sprawdzić, czy system rodziny pochodzenia ma istotne znaczenie w odraczaniu zadań rodzicielskich przez osoby w okresie wczesnej dorosłości. Przeprowadzone analizy 
potwierdziły występowanie istotnych różnic w ocenie systemów rodziny pochodzenia między małżonkami niepodejmującymi zadań rodzicielskich a mającymi dzieci. Różnice istotne statystycznie wystapiły pomiędzy mężczyznami, którzy odraczają realizację zadań rozwojowych a ojcami. Wymiarem różnicującym okazał się wymiar elastyczności. Systemy rodzin pochodzenia ojców charakteryzowały się wyższym zrównoważeniem elastyczności od systemów rodzin pochodzenia mężczyzn bezdzietnych, co znalazło też potwierdzenie w różnicy we wskaźniku elastyczności. Wśród wskaźników wymiaru elastyczności Andrzej Margasiński wymienia ,zakres przejmowania przywództwa, style prowadzenia negocjacji, zasady określające związki między członkami rodziny" (Margasiński, 2013, s. 13). Można więc wnioskować, że rodziny pochodzenia badanych mężczyzn niepodejmujących zadań rodzicielskich mogły być mniej skłonne do zmian w obrębie systemu rodzinnego.

Warto zwrócić uwagę na różnicę w ocenie spójności rodzin pochodzenia między kobietami i mężczyznami z grupy osób niepodejmujących zadań rodzicielskich. Mimo iż jest to różnica istotna jedynie na poziomie tendencji statystycznej, może to wskazywać na pewien kierunek ważny dla dalszych badań. Bezdzietni mężczyźni oceniali swoje rodziny pochodzenia jako bardziej splątane niż bezdzietne kobiety. Może to sygnalizować, że rodziny te mogła charakteryzować nadmierna bliskość między członkami rodziny. Przejawia się ona na przykład w przekraczaniu granic między podsystemami w rodzinie czy w trudności z separowaniem się od rodziny pochodzenia. Jednocześnie nie wykazano istnienia różnic w tym zakresie pomiędzy mężczyznami bezdzietnymi, a tymi, którzy są ojcami. Badacze nie są zgodni co do jednoznacznego interpretowania skali splątania w modelu Olsona (por. Kuryś, 2013; Margasiński, 2006). Zwraca się uwagę, że splątanie nie powinno być utożsamiane $\mathrm{z}$ maksymalną spójnością (Margasiński, 2006, s. 71). Mimo to bliskość emocjonalna jest bardzo ważną właściwością systemów rodzinnych, gdyż ,stwarza szczególnie dogodne warunki przekazu psychicznego, a więc wymiany i przejmowania doświadczeń osób bliskich" (Tyszkowa, 1996, s. 126). Wyniki badań Farnickiej wskazują, że „W rodzinach o pozytywnym klimacie emocjonalnym zauważono podobieństwo nie tylko wartości rodzicielstwa i normatywnej kolejności jego realizacji, ale i uwarunkowań i oczekiwań związanych z tym obszarem" (Farnicka, 2013, s. 79). Jednocześnie umiejętność separowania się od rodziny pochodzenia wskazywana jest jako jedno z podstawowych zadań stojących przed małżonkami w pierwszych latach małżeństwa (Goldenberg, Goldenberg, 2006; Kołbik, 1999; Plopa, 2011). Problemy w tym obszarze mogą utrudniać podejmowanie zadań wobec rodziny aktualnej.

Przeprowadzone analizy nie wykazały istnienia innych istotnych różnic między grupami małżonków niepodejmujących zadań rodzicielskich, a tymi małżonkami, którzy mają dzieci, w ocenie spójności rodziny pochodzenia oraz komunikacji w rodzinie pochodzenia. Dotychczasowe nieliczne badania wskazywały na negatywny obraz ról rodzicielskich (szczególnie macierzyńskich) wyniesionych z domów rodzinnych przez osoby świadomie bezdzietne (Bartosz, Bartak, 2009; Carmichael, Whitaker, 2007; Park, 2005; Peterson 2015). Nie znalazło to odzwierciedlenia w wynikach prezentowanych analiz. Być może ocena jakości relacji i komunikacji w systemie rodziny pochodzenia nie wiąże się dla badanych osób z percepcją ról odgrywanych przez rodziców. Jak wskazuje Mieczysław Plopa, obraz rodziców, który tworzy się w umyśle dziecka, przekształca się w czasie przechodzenia kolejnych okresów rozwojowych (Plopa, 2005). Niewykluczone, że istotne jest to, iż grupę kryterialną stanowiły osoby będące w związkach małżeńskich, w omawianych badaniach natomiast większość respondentów była singlami bądź pozostawała w związkach nieformalnych.

Ciekawych wyników dostarczyło porównanie ocen funkcjonowania rodziny pochodzenia $\mathrm{z}$ aktualnym systemem rodzinnym $\mathrm{w}$ obu grupach. Wynika z niego, że respondenci zarówno z grupy kryterialnej, jak i kontrolnej uznają własne rodziny za lepiej funkcjonujące - o wyższym poziomie zrównoważenia w obszarach spójności i elastyczności oraz o lepszej komu- 
nikacji. Wyniki te okazały się porównywalne w obu grupach.

Prezentowane badania nie są wolne od ograniczeń. Przyjęte postępowanie badawcze uniemożliwia wnioskowanie o zależnościach przyczynowo-skutkowych między funkcjonowaniem systemów rodzinnych a podejmowaniem zadań rodzicielskich. Należy pamiętać, że badaniami objęto grupę o określonej charakterystyce socjodemograficznej. Przedstawione badania otwieraja pole do dalszych poszukiwań teoretycznych i badawczych, takich jak chociażby rozszerzenie grupy badanej o osoby będące w związkach kohabitacyjnych.

\section{BIBLIOGRAFIA}

Abma J.C., Martinez G.M. (2006), Childlessness Among Older Woman in the United Statefs: Trends and Profiles. Journal of Marriage and Family, 68(4), 1045-1057.

Bakiera L. (2003), Rodzicielstwo a rozwój dorosłych w wieku średnim. W: B. Harwas- Napierała (red.), Rodzina a rozwój człowieka dorosłego, 47-62. Poznań: Wydawnictwo Naukowe UAM.

Bakiera L. (2004), Pełnienie ról rodzicielskich a rozwój dorosłych w średnim wieku. Psychologia Rozwojowa, 2, 37-46.

Bartosz B. Bartak K. (2010), Zamierzona bezdzietność wyborem autobiograficznym kobiet. W: B. Bartosz (red.), Wymiary kobiecości i męskości: Od psychobiologii do kultury. Warszawa: Eneteia.

Bielawska-Batorowicz E. (2014), Trudności w realizacji planów prokreacyjnych i ich skutki dla rodziny. W: I. Janicka, H. Liberska (red.), Psychologia rodziny, 412-436. Warszawa: Wydawnictwo Naukowe PWN.

Cannold L. (2004), Declining marriage rates and gender inequity in social institutions. Towards an adequately complex explanation for childlessness. People and Place, 12, 1-11.

Carmichael G., Whittaker A. (2007), Choice and circumstance: qualitative insights into contemporary childlessness in Australia. European Journal of Population, 23(2), $1^{\text {st }}$ June, 111-143.

CBOS (2010), Postawy prokreacyjne Polaków. Komunikat z badań. Warszawa.

CBOS (2012), Potrzeby prokreacyjne oraz preferowany i realizowany model rodziny. Komunikat z badań, Warszawa.

CBOS (2013a), O roli kobiety w rodzinie. Komunikat z badań. Warszawa.

CBOS (2013b), Postawy prokreacyjne kobiet. Komunikat z badań. Warszawa.

CBOS (2013c), Rodzina, jej współczesne rozumienie i znaczenie. Komunikat z badań. Warszawa.

Cierpka A. (2013), Tożsamość i narracje w relacjach rodzinnych. Warszawa: Eneteia.

Cowan C.P., Cowan P.A. (1995), Interventions to ease the transition to parenthood: Why they are needed and what they can do. Family Relations, 44(4), 412-423.

DeLyser G. (2012), At midlife, intentionally childfree women and their experiences of regret. ClinSocWor Journal, 40, 66-74, http://docslide.net/documents/at-midlife-intentionally-childfree-women-and-their-experiences-of-regret.html (dostęp: 4.03.2016).

Dolińska B. (2014), Bezdzietność, perspektywa społeczno-kulturowa. Sopot: Wydawnictwo Smak Słowa.

Duvall E.M. (1977), Marriage and family development. Philadelphia: Lippincott.

Dyczewski L. (2007), Małżeństwo i rodzina upragnionymi wartościami młodego pokolenia. W: L. Dyczewski (red.), Małżeństwo i rodzina w nowoczesnym społeczeństwie. Lublin: Wydawnictwo KUL.

Farnicka M. (2011), Przemiany realizacji zadań rozwojowych: ewolucja czy rewolucja? Zielona Góra: Wydawnictwo Uniwersytetu Zielonogórskiego.

Farnicka M. (2013), Między wyborem a przymusem. Rodzina a sposób radzenia sobie w różnych sytuacjach życiowych. Warszawa: Wydawnictwo Difin.

Frejka T., Sobotka T. (2008), Fertility in Europe: Diverse, delayed and below replacement. Demographic Research, 19, 15-46.

Gillespie R. (2000), When no means no: Disbelief, disregard and deviance as discourses of voluntary childlessness. Women's Studies International Forum, 23(2), 223-234.

Gillespie R. (2003), Childfree and feminine: Understanding the gender identity of voluntary childless women. Gender and Society, 17(1), 122-136. 
Goldenberg H., Goldenberg I. (2006), Terapia rodzin. Kraków: Wydawnictwo Uniwersytetu Jagiellońskiego. Golombok S. (2015), Modern families: Parents and children in new family forms. Cambridge: Cambridge University Press.

Gurba E. (2009), Wczesna dorosłość. W: B. Harwas-Napierała, J. Trempała (red.), Psychologia rozwoju czlowieka, t. 2, 202-233. Warszawa: Wydawnictwo Naukowe PWN.

GUS (2016), Matżeństwa oraz dzietność w Polsce. Warszawa: Zakład Wydawnictw Statystycznych.

Hara T. (2008), Increasing childlessness in Germany and Japan: Toward a childless society? International Journal of Japanese Sociology, 17(1), 42-62.

Harwas-Napierała B. (2003), Zmiany w funkcjonowaniu rodziny i ich konsekwencje dla rozwoju rodziców. W: B. Harwas-Napierała (red.), Rodzina a rozwój człowieka dorosłego. Poznań: Wydawnictwo Naukowe UAM.

Harwas-Napierała B. (2009), Rodzina jako wartość a współczesność. W: B. Harwas-Napierała (red.), Rodzina jako wartość w rozwoju człowieka, 11-23. Poznań: Wydawnictwo Naukowe UAM.

Havighurst R. (1981), Developmental Tasks and Education. New York-London: Longman

Kaźmierczak M. (2015), Oblicza empatii w procesie adaptacji do rodzicielstwa. Warszawa: Wydawnictwo Naukowe Scholar.

Keizer R., Dykstra P., Jansen A. (2008), Pathwaysintochildlesness. Evidence of genered life course dynamics. Journal of Biosocial Science, 40, 863-878.

Kemkes-Grottenthaler A. (2003), Postponing or rejection parenthood? Results of a survey among female academic professionals. Journal of Biosocial Science, 35(2), 213-226.

Kocot-Górecka K. (2014), Zmiany demograficzne w Polsce po 1989 r. i ich wybrane konsekwencje. W: I. E. Kotowska (red.), Niska dzietność w Polsce w kontekście percepcji Polaków Raport tematyczny, s. 9-18. Warszawa: Ministerstwo Pracy i Polityki Społecznej i Centrum Rozwoju Zasobów Ludzkich.

Kołbik I. (1999), Lojalność rodzinna. W: B. de Barbaro (red.), Wprowadzenie do systemowego rozumienia rodziny, 78-84. Kraków: Wydawnictwo Uniwersytetu Jagiellońskiego.

Kotowska I. (2009), Zmiany aktywności zawodowej kobiet a modele rodziny w Europie. W: M. Sikorska (red.), Być rodzicem we wspótczesnej Polsce, 146-178. Warszawa: Wydawnictwo Uniwersytetu Warszawskiego.

Kotowska I. (2014), Niska dzietność w Polsce w kontekście percepcji Polaków. Diagnoza spoleczna 2013. Raport tematyczny. Warszawa: Ministerstwo Pracy i Polityki Społecznej i Centrum Rozwoju Zasobów Ludzkich.

Kuryś K. (2013), System rodzinny wobec zmian rozwojowych. Poznań: Wydawnictwo Naukowe UAM.

Kwak A. (2014), Współczesne zwiqzki heteroseksualne: Małzeństwa (dobrowolnie bezdzietne), kohabitacje, LAT. Warszawa: Wydawnictwo Akademickie Żak.

Letherby G. (1994), Mother or not, mother or what? Problems of definition and identity. Women's Studies International Forum, 17, 525-532.

Letherby G. (2002), Childless and bereft?: Stereotypes and realities in relation to "voluntary" and "involuntary" childlessness and womanhood. Sociological Inquiry, 72(1), 7-20.

Liberska H. (2003), Realizacja zadań rozwojowych dorosłości a rozwój indywidualny. W: B. Harwas-Napierała (red.), Rodzina a rozwój człowieka dorosłego, 63-99. Poznań: Wydawnictwo Naukowe UAM.

Margasiński A. (2006), Rodzina w modelu Kołowym i Faces IV Davida H. Olsona. Nowiny Psychologiczne, $4,69-86$.

Margasiński A. (2013), Skale Oceny Rodziny. Polska adaptacja FACES IV - Flexibility and Cohesion Evaluation Scales Davida H. Olsona. Podręcznik. Warszawa: Pracownia Testów Psychologicznych Polskiego Towarzystwa Psychologicznego.

Margasiński A. (2015), Teoria i wybrane modele systemów rodzinnych. W: A. Margasiński (red.), Rodzina w ujęciu systemowym. Teoria i badania, 6-32. Warszawa: Pracownia Testów Psychologicznych Polskiego Towarzystwa Psychologicznego.

Martowska K. (2015), Cechy rodziny pochodzenia a przystosowanie społeczno-emocjonalne młodych kobiet. W: A. Margasiński (red.), Rodzina w ujęciu systemowym. Teoria i badania, 33-51. Warszawa: Pracownia Testów Psychologicznych Polskiego Towarzystwa Psychologicznego.

Matuszewska M. (2003), Funkcjonowanie w rolach rodzicielskich jako źródło rozwoju młodych dorosłych. W: B. Harwas-Napierała (red.), Rodzina, a rozwój człowieka dorosłego, 25-46. Poznań: Wydawnictwo Naukowe UAM. 
McQuillan J., Greil A., Schreffler K., Wonch-Hill P., Gentzler K., Hathoat J. (2012), Does the reason matter? Variations in childlessness concerns among U.S. women. Journal of Marriage and Family, 75(5), $1^{\text {st }}$ October, 1166-1181.

Mynarska M. (2009), Individual fertility choices in Poland. Warszawa: UKSW.

Mynarska M. (2011a), Kiedy mieć dziecko? Jakościowe badanie procesu odraczania decyzji o rodzicielstwie. Warszawa: Zeszyty Naukowe Instytut Statystyki i Demografii SGH, nr 11.

Mynarska M. (2011b), Kto planuje mieć dzieci w Polsce do 2015 roku?, Komunikaty Naukowe Studia Demograficzne, 1(159), 75-98.

Mynarska M., Matysiak A., Rybińska A. (2014), Którędy do bezdzietności? Analiza ścieżek kobiet, które nigdy nie zostały matkami. W: A. Matysiak (red.), Nowe wzorce formowania i rozwoju rodziny w Polsce, 105-131. Warszawa: Wydawnictwo Naukowe Scholar.

Olson D. (2010), FACES IV \&Circumplex Model. Validation Study. Journal of Marital and Family Therapy, www.facesiv.com (dostęp: 10.10.2016).

Olson D., Gorall D. (2006), FACES IV and the Circumplex Model. Minnesota: Life Innovations.

Park K. (2005), Choosing childlessness: Weber's typology of actions and motives of the voluntarily childless. Sociological Inquiry, 75(3), $1^{\text {st }}$ August, 372-402.

Peterson H. (2015), Fifty shades of freedom. Voluntary childless women's ultimate liberation. Women's Studies International Forum, 53, $1^{\text {st }}$ November, 182-191.

Plopa M. (2005), Psychologia rodziny. Teoria i badania. Kraków: Oficyna Wydawnicza Impuls.

Plopa M. (2011), Rodzicielstwo, jako wyzwanie dla małżeństwa: perspektywa teorii systemowej. W: H. Liberska, A. Malina (red.), Wybrane problemy wspótczesnych matzeństw i rodzin, 15-42. Warszawa: Wydawnictwo Difin.

Radochoński M. (2009), Osobowość antyspołeczna, Rzeszów: Wydawnictwo Uniwersytetu Rzeszowskiego.

Rich S., Taket A., Graham M, Shelley J. (2011), "Unnatural", "unwomanly", "uncreditable", and "undervaluated": The significance of being a childless woman in Australian society. Gender Issues, 28(4), 226-247.

Rostowska T. (1995), Transmisja międzypokoleniowa w rodzinie w zakresie wybranych wymiarów osobowości. Łódź: Wydawnictwo Uniwersytetu Łódzkiego

Rostowska T. (2000), System wartości rodziców i dzieci jako zadanie rozwojowe. W: D. Kornas-Biela (red.), Rodzina: źródło życia i szkoła miłości, 217-230. Lublin: Towarzystwo Naukowe KUL.

Rowland D.T. (2007), Historical trends in childlessness. Journal of Sociology, 18(1), 1311-1337.

Seiz M. (2013), Voluntary childlessness in Southern Europe: The case of Spain. Population Review, 52(1), $110-128$.

Szlendak T. (2010), Socjologia rodziny. Warszawa: Wydawnictwo Naukowe PWN.

Tanturri M.L., Mencarini L. (2008), “Childless or childfree?” An insight into voluntary childlessness in Italy. Population Development Review, 34(1).

Trempała J. (2006), Modele rozwoju psychicznego czas i zmiana. Bydgoszcz: Wydawnictwo Uczelniane Akademii Bydgoskiej.

Tyszkowa M. (1996), Jednostka a rodzina: interakcje, stosunki, rozwój. W: M. Przetacznik-Gierowska, M. Tyszkowa (red.), Psychologia rozwoju człowieka, 124-150. Warszawa: Wydawnictwo Naukowe PWN.

Wrzesień W. (2003), Jednostka - rodzina - pokolenie. Studium relacji międzypokoleniowych w Polsce. Poznań: Wydawnictwo Naukowe WAM. 